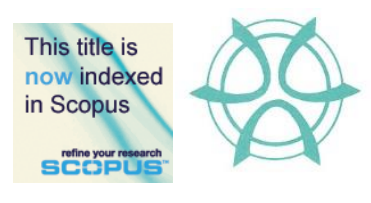

PLANNING MALAYSIA:

Journal of the Malaysian Institute of Planners

VOLUME 17 ISSUE 1 (2019), Page 82 - 93

\title{
AN EVALUATION OF FACTORS CAUSING VARIANCE IN PROPERTY ASSESSMENT
}

\author{
Moses Idowu Atilola ${ }^{1}$, Azizah Ismail ${ }^{2}$, Kamalahasan Achu ${ }^{3}, \&$ Ahmad \\ Ariffian Bujang ${ }^{4}$ \\ ${ }^{1}$ School of Environmental Studies \\ FEDERAL POLYTECHNIC OFFA, NIGERIA \\ ${ }^{2,3,4}$ Faculty of Geoinformation and Real Estate \\ UNIVERSITI TEKNOLOGI MALAYSIA
}

\begin{abstract}
Most of the previous studies on causes of valuation variance have concentrated on non-statutory valuation, with little attention to statutory valuation in both developed and developing countries, leaving a gap in the body of knowledge in this regard. Purposive sampling was adopted to select samples from registered estate surveyors and valuers in Kwara State, Nigeria. The data collection was done through a survey questionnaire given to 33 valuers and the Relative Importance Index (RII) was used to analyse the data collected. Findings showed that factors that fell within the range index of significant factors (0.841 to 0.979) are: experience in rating valuation, comprehensiveness of the law, unrealistic valuation assumption and availability of market indices for the input variables. Other significant factors are explicitness of the law, integrity of the valuer, valuer negligence, absence of quality control and training in rating valuation. The findings have practical implications on rating valuation stakeholders.
\end{abstract}

Keywords: rating administration, rateable value, significant factors, valuation 
PLANNING MALAYSIA

Journal of the Malaysia Institute of Planners (2019)

\section{INTRODUCTION}

The essence of valuation in rating is to ensure fairness in property assessment (Ross \& Duncan, 2012; Kelly, 2013). Valuation is the foundation of rating administration which consists of valuation, billing, collection and enforcement (UN-HABITAT, 2013; Bond \& Brown 2017). The significance of valuation in rating administration cannot be over-emphasised; the World Bank even recognises this fact. As a result of the significance of valuation in rating administration, the World Bank often encourages the preparation of a comprehensive valuation list (Kelly \& Musunu, 2000; Kayuza, 2014).

Valuation variance is the discrepancy in opinion of values between two or more valuers on the same property (Babawale, 2013; Mohammad, Ali, \& Jasimin, 2018). The essence of the display of valuation list is to rectify the discrepancy between the values on the draft valuation list and that which the objectors claim to be the correct values (Bond \& Brown, 2017). The effects of valuation variance in rating include tax evasion, tax avoidance and unrest, among many others (Bello, 2014; Fatoki, 2014; Al-Mustapha \& Hamza, 2016; Atilola, Kamarudin, Achu, \& Ibisola, 2016).

The causes of valuation variance has been an issue of discussion in the academia, among professionals and the judiciary, particularly in the developed world such as the UK and Australia. There have been many cases on this subject matter. The case of Singer and Friedlander Ltd. v John D. Wood and Co. provides some insights into the nature of valuation and why there is variation in property valuation. Part of the judgement of Watkins J. presented in Crosby's (2000) study reads as follows:

The valuation of land by trained, competent and careful professional men is a task which rarely, if ever, admits of precise conclusion. Often beyond certain well-founded facts so many imponderables confront the valuer that he is obliged to proceed on the basis of assumptions. Therefore, he cannot be faulted for achieving a result which does not admit to some degree of error. Thus, two able and experienced men, each confronted with the same task, might come to different conclusions without anyone being justified in saying that either of them has lacked competence and reasonable care, still less integrity, in doing his work ... Valuation is an art, not a science. Pinpoint accuracy in the result is not, therefore, to be expected by he who requests the valuation.

From the judgement of Watkins J., it is clear that variation in valuation is inevitable and the causes of variance are: valuer training, valuer negligence, valuer integrity and valuation assumptions. The causes of variation in valuation from empirical studies revealed, among others, are valuer experience, client 
Moses Idowu Atilola, Azizah Ismail, Kamalahasan Achu, \& Ahmad Ariffian Bujang

An Evaluation of Factors Causing Variance in Property Assessment

influence, availability of market indices, lack of sanctions for professional negligence and misconduct, and absence of quality control (Achu, 2013; Akinjare, Iroham, \& Oloke, 2013; Effiong, 2015; Adegoke, 2016; Munshifwa et al., 2016).

Valuation discrepancies have been a major issue that has provoked a congressional bill in the US; leading to two major commissions of enquiry in the UK and one commission in Australia (Babawale, 2008). The motivation for studies on property valuation variance arose from the study of Hager and Lord (1985) in the UK, which tried to establish the existence of variance, rather than investigating factors causing the variance in valuation. The works of Boyd and Irons (2002), Nasir (2006), Ayedun, Oloyede and Durodola (2012), Akinjare et al. (2013), Effiong (2015), Munshifwa et al. (2016), and Adegoke (2016) evaluated the factors influencing variance in various purposes of valuation. Apart from the study of Munshifwa et al. (2016) that identified and evaluated the factors causing variance in rateable values in Zambia, no other studies (both in the developed and developing nations) have evaluated factors influencing variance in rating valuation to the best of the researchers' knowledge. However, all the factors evaluated by Munshifwa et al. (2016) cannot be adopted and evaluated in the Nigerian context. This is due to the differences in rating laws and regulations, and valuation environment processes. Hence, there is a need to identify and evaluate such factors that are peculiar to the Nigerian valuation industry. This study, therefore, fills this observed gap in knowledge by exploring factors responsible for variance in rateable values in Nigeria.

The scope of this study is limited to Kwara State, Nigeria being one of the states in the country with a long standing history in rating valuation. This study therefore provides an answer to the question of what are the factors that significantly influenced variance in rateable values?

\section{FACTORS CAUSING VARIANCE IN PROPERTY VALUATION}

From the study of Harvard (2001) in the UK on valuation variance and valuer behaviour, it was revealed that the causes of valuation variance include inexperience of the valuer, understanding of comparable evidence, difference of opinion between valuers, error in the survey, procedural errors, client influence, different valuation methodologies, insufficient depth of investigation and quality control. Boyd and Irons (2002) conducted a study on the variance that existed between five valuers in mortgage valuation on the popular Meyer Centre case in Australia. The study investigated the causes of the variance by evaluating the decision of the Queensland Supreme Court on this matter. Arising from the pronouncement of the Court, wrong valuation methodology, incorrect valuation data, and value analysis were the causes of variation in the Meyer Centre case. The causes of valuation variation in Meyer Centre case could be summarised as an act of negligence. 
PLANNING MALAYSIA

Journal of the Malaysia Institute of Planners (2019)

Nasir (2006) carried out a study on valuation variation in commercial properties in Malaysia. It was revealed from the study that the variance that existed was below the $\pm 10 \%$ stipulated by the Board of Valuers, Appraisers and Estate Agent, Malaysia (BOVAEA). The study submitted that the imposition of sanctions by BOVAEA for valuation variation of more than $\pm 10 \%$ might have resulted in the low level of variation that was obtained in the study area.

The investigation carried out by Akinjare et al. (2013) on the causes of valuation variance in Lagos is one of the recent studies in Nigeria that tried to trace the root cause of variation in valuation. One hundred and thirty questionnaires were administered on valuation firms and was analysed using RII. The authors categorised the factors into endogenous and exogenous variables. Each factor had four variables. The four key factors that influence variation based on the RII result are: use of different input variables, use of a different method of valuation for the endogenous variable, while lack of adequate market information and client influence was identified as the exogenous variables.

The study of Ayedun et al. (2012) in Lagos and Effiong (2015) in Calaba and Uyo, all located in Nigeria, focused on causes of variance and inaccuracies in non-statutory valuations. The findings from Ayedun et al. (2012) suggested that educational background and availability of market information are the prominent causes. While that of Effiong (2015) revealed that lack of standard, lack of market comparable data, lack of regulatory framework, methods adopted, client influence, inadequate training, imperfect knowledge of property market, assumption on cost per square meter, lack of experience and failure to discipline valuers on negligence matters were the causes. Another study that investigated the causes of valuation variance and valuation inaccuracy in non-statutory valuation in Nigeria was by Adegoke (2016). One hundred and sixty three questionnaires were used for collecting the data from estate surveying and valuation firms and RII was used for the analysis. The RII results show that the causes of variance and inaccuracy in valuation are valuer skill, valuer judgement, valuer experience and problems of relevant data with an RII of 0.922, 0.921, 0.908 and 0.890 respectively.

A recent study by Munshifwa et al. (2016) applied 'mental models' to assess how valuers in Zambia interpret the Rating Act on the definition of 'rateable value' and 'market price'. Questionnaires were administered to 18 valuers in the public and private sectors. The study revealed that absence of a centralised market (15\%), lack of comparable information (15\%), differences in comparable (12\%) and calculation/measurement errors (8\%) as the principal causes of rating valuation variance. While factors such as negligence, lack of experience, too much assumption, adoption of difference in valuation method, corruption and market stability accounted for $5 \%$ of the cause of valuation variance. The factors that did not seem to be significant were lack of market transparency, absence of consultation amongst assessors, lack of information 
Moses Idowu Atilola, Azizah Ismail, Kamalahasan Achu, \& Ahmad Ariffian Bujang

An Evaluation of Factors Causing Variance in Property Assessment

sharing amongst appraisers, time difference between valuation dates and ambiguity in valuation instruction. These factors accounted for $2 \%$ of the cause of valuation variance. Whereas factors such as misapplication of the rating Act, insufficient market research and overwhelming workload had a low response rate of $3 \%$ of the cause.

Furthermore, another study of variance in rateable values is by Kelly and Musunu (2000). The researchers evaluated the 1993 rating assessment that was carried out in the local authorities in the city of Dar es Salaam, Tanzania. It was concluded that lack of quality control and sanctions for wrong assessment could be attributed to the lapses observed in the 1993 assessment. Other studies that have commented on the likely causes of variance in property tax assessment are by Babawale and Nubi (2011), Oni and Ajayi (2011), Atilola (2013) and Babawale (2013). These authors attributed the causes of variance in rateable values to non-robustness of the law in terms of its comprehensiveness and explicitness. For instance, Oni and Ajayi (2011) suggested that the discretionary provisions on the assessment of property under the Land Use Charge Law of Lagos State of 2001 resulted in wide variances between assessed values and the objector values.

From the review of relevant studies on valuation variance, it can be concluded that the aspect of rating valuation has not been explored in Nigeria as most of the earlier studies focused on valuation inaccuracy relating to nonstatutory valuations in Nigeria. In addition, the contributions of Babawale and Nubi (2011), Atilola (2013) and Babawale (2013) were not on property rating law but on other property taxes in Nigeria.

In order to identify factors causing variance in rateable values, the literature on variance in valuation as a whole was explored since there is little research on this phenomenon in rating valuation to the best of the researchers' knowledge. From the review of the literature on the causes of variance in valuation, 13 factors were identified. The 13 factors were grouped into three as valuer characteristics, the legal factors and the valuation environment and process factors, as follows:

a. Valuer characteristics: experience in rating valuation, unrealistic valuation assumption, integrity of the valuer, valuer negligence, training in rating valuation, professional qualification and academic qualification;

b. Legal factors: comprehensiveness of the law and explicitness of the law; and

c. Valuation environment and process factors: availability of market indices for input variables, client influence, availability market indices for input variables and quality control. 
PLANNING MALAYSIA

Journal of the Malaysia Institute of Planners (2019)

\section{METHODOLOGY}

The target population for this study is informed by the legal provision in Nigeria, which specifies that only valuers that could comment on issues of property valuation (Estate Surveyors and Valuers Registration Act 2007; Adegoke 2016). For this reason the valuers in Nigeria were the target population of this study. There were 1,149 Registered Valuers as at December 31, 2015 as indicated in Estate Surveyors and Valuers Registration Board of Nigeria [ESVABON], (2014). Out of the 1,149 valuers in Nigeria, only 33 reside in Kwara State (NIESV Kwara State Branch, 2015). The 33 valuers represented the sample frame and this was adopted as the sample size because the sample frame was small.

The data was collected through a survey questionnaire that was selfadministered on the 33 Registered Valuers. Out of the 33 questionnaires that were administered, 19 were retrieved and were valid for the analysis. This indicates 57.8\% response rate. According to Arowosegbe and Muhamed (2015), a 20 to $30 \%$ response rate is common in survey questionnaires. The validity of the instrument was based on expert validity advocated by Creswell (2014). The reliability of the data was based on Cronbach's Alpha. The Cronbach's Alpha of 0.685 was obtained, and according to Hair, Black, Babin, Anderson and Tatham (1998), is acceptable when the sample size is small.

The questionnaires consisted of closed-ended questions with five options based on the Likert scale of extremely influential (5) to not at all influential (1). Relative importance index, which is often abbreviated as RII, is a statistical method to determine ranking of different causes (Salleh 2009). The information gathered from the survey questionnaire was analysed with RII, which is often expressed as:

$$
\mathrm{RII}=\sum \mathrm{W} / \mathrm{AN}
$$

Where ' $\mathrm{W}$ ' is the weight specified to each variable by the respondents, this ranges from 5 to 1 ; ' $A$ ' the highest weight (that is 5 ); ' $\mathrm{N}$ ' the aggregate respondents. Higher scores indicate higher perceived significant of the respective factors.

\section{DATA PRESENTATION AND ANALYSIS}

The RII result from the analysis is presented in Table 1 . In order to identify the factors that have significant contributions, the result was subjected to further evaluation based on a decision rule in Table 2 .

Table 1: Relative importance index of factors causing variance in rateable values

\begin{tabular}{llllllll}
\hline Factors Causing Valuation Variance & $\mathbf{5}$ & $\mathbf{4}$ & $\mathbf{3}$ & $\mathbf{2}$ & $\mathbf{1}$ & Sum & RII \\
\hline Valuer Characteristic Factors & & & & & & \\
\hline Experience in Rating Valuation & 17 & 2 & - & - & - & 93 & 0.979 \\
\hline Unrealistic Valuation Assumption & 12 & 7 & - & - & - & 88 & 0.926 \\
\hline Integrity of the Valuer & 5 & 7 & 6 & 1 & - & 83 & 0.874 \\
\hline
\end{tabular}


Moses Idowu Atilola, Azizah Ismail, Kamalahasan Achu, \& Ahmad Ariffian Bujang An Evaluation of Factors Causing Variance in Property Assessment

\begin{tabular}{llllllll}
\hline Valuer Negligence & 7 & 11 & 1 & - & - & 82 & 0.863 \\
\hline Training in Rating Valuation & 8 & 8 & 3 & - & - & 81 & 0.853 \\
\hline Professional Qualification & 1 & 11 & 7 & - & - & 70 & 0.737 \\
\hline Academic Qualification & - & 12 & 7 & - & - & 69 & 0.726 \\
\hline Legal Factors & & & & & & \\
\hline$\quad$ Comprehensiveness of the Rating Law & 17 & 2 & - & - & - & 93 & 0.979 \\
\hline Explicitness of the Rating Law & 11 & 7 & 1 & - & - & 86 & 0.905 \\
\hline Valuation Environment and Process Factors & & & & & & \\
\hline Market Indices for the Input Variables & 12 & 7 & - & - & - & 88 & 0.926 \\
\hline Absence of Quality Control & 8 & 8 & 3 & - & - & 81 & 0.853 \\
\hline Client Influence & 5 & 2 & 7 & 4 & 1 & 63 & 0.663 \\
\hline Absence of Professional Sanctions for & - & 4 & 14 & - & 60 & 0.632 \\
$\quad$ Negligence and Misconduct & & & & & & & \\
\hline Source: Field survey (2016) & & &
\end{tabular}

In setting the decision rule for identifying factors that contribute significantly to variance in rateable values, the RII figure was classified into two groups of 'accept' and 'reject' as shown in Table 2. In this analysis, the highest RII was 0.979 and the lowest was 0.632 . The range of the RII was $0.347(0.979$ to 0.632 ). When 0.347 was divided by 5 , the result was 0.0694 . For each scale of index, 0.0694 was added starting from the lowest RII score. The decision rule was that only those where the RII score fell within the very significant and the extremely significant were considered to contribute significantly to variance in rateable values. This type of decision rule was used by Ismail, Bujang, Jiram, Zarin and Jaafar (2015). The result of the application of RII decision rule of Table 2 to Table 1 is presented in Table 3 .

Table 2: Relative importance index decision rule

\begin{tabular}{lcc}
\hline Scale of Index & Range of Index & Decision Rule \\
\hline Not at all Significant & 0.632 to 0.701 & Reject \\
Slightly Significant & 0.702 to 0.771 & Reject \\
Somewhat Significant & 0.772 to 0.840 & Reject \\
Very Significant & 0.841 to 0.910 & Accept \\
Extremely Significant & 0.911 to 0.979 & Accept \\
\hline
\end{tabular}

Source: Field survey (2016)

From Table 3, it was revealed that factors such as experience in rating valuation, comprehensiveness of the rating law, unrealistic assumption, market indices for the input variables and explicitness of the rating law were extremely significant causes of variance in rateable value by falling within RII range index of 0.911 to 0.979 . Furthermore, integrity of the valuer, valuer negligence, absence 
of quality control and training in rating valuation were very significant having fallen within the RII range index of 0.841 to 0.910 . However, none of the factors were somewhat significant, as none fell within the RII range index of 0.772 to 0.840. Nevertheless, factors such as professional qualification and academic qualification were within the RII range index of 0.702 to 0.771 making them slightly significant. Client influence and absence of professional sanctions were not at all significant, being in the range of 0.632 to 0.701 .

Table 3: Significant factors causing variance in rateable values

\begin{tabular}{|c|c|c|c|}
\hline Scale & $\begin{array}{l}\text { RII Range } \\
\text { Index }\end{array}$ & $\begin{array}{c}\text { Factors Causing Valuation } \\
\text { Variance }\end{array}$ & $\begin{array}{c}\text { RII } \\
\text { Score }\end{array}$ \\
\hline \multirow{5}{*}{$\begin{array}{l}\text { Extremely } \\
\text { Significant }\end{array}$} & \multirow[t]{5}{*}{0.911 to 0.979} & Experience in rating valuation & 0.979 \\
\hline & & Comprehensiveness of the rating law & 0.979 \\
\hline & & Unrealistic valuation assumption & 0.926 \\
\hline & & $\begin{array}{l}\text { Market indices for the input } \\
\text { variables }\end{array}$ & 0.926 \\
\hline & & explicitness of the rating law & 0.926 \\
\hline \multirow{4}{*}{$\begin{array}{l}\text { Very } \\
\text { Significant }\end{array}$} & \multirow[t]{4}{*}{0.841 to 0.910} & Integrity of the valuer & 0.863 \\
\hline & & Valuer negligence & 0.863 \\
\hline & & Absence of quality control & 0.853 \\
\hline & & Training in rating valuation & 0.853 \\
\hline $\begin{array}{l}\text { Somewhat } \\
\text { significant }\end{array}$ & 0.772 to 0.840 & - & - \\
\hline \multirow{2}{*}{$\begin{array}{l}\text { Slightly } \\
\text { significant }\end{array}$} & \multirow[t]{2}{*}{0.702 to 0.771} & Professional qualification & 0.737 \\
\hline & & Academic qualification & 0.726 \\
\hline \multirow{2}{*}{$\begin{array}{l}\text { Not at all } \\
\text { significant }\end{array}$} & \multirow[t]{2}{*}{0.632 to 0.701} & Clients' influence & 0.663 \\
\hline & & $\begin{array}{l}\text { Absence of professional sanctions } \\
\text { for negligence and misconduct }\end{array}$ & 0.632 \\
\hline
\end{tabular}

\section{DISCUSSION}

From the data analysis it was revealed that the factors that could contribute significantly to the causes of variance in rateable values are nine in number. These factors satisfied the decision rule set for the determination of significant factors. These factors need to be considered when rating valuation is to be carried out. Wide variance in valuation has the following implication: the essence of valuation for whatever purpose would not be achieved, the image of the profession of estate surveying and valuation could be in disrepute and the professional could be liable for a negligent act (Babawale, 2008; Al-Mustapha \& Hamza, 2016; Atilola et al., 2016; Munshifwa et al., 2016).

Some of the factors identified in this study had been identified in previous studies in developed nations such as the UK and Australia (Bretten \& Wyatt, 2001; Harvard, 2001; Boyd \& Irons, 2002; Bond \& Brown, 2017). The factors have also been identified in the emerging property markets of Malaysia, Zambia 
Moses Idowu Atilola, Azizah Ismail, Kamalahasan Achu, \& Ahmad Ariffian Bujang

An Evaluation of Factors Causing Variance in Property Assessment

and Tanzania (Kelly \& Musunu, 2000; Nasir, 2006; Achu, 2013; Munshifwa et al., 2016). Moreover, the factors identified in this study are in agreement with some of the factors identified in studies such as Akinjare et al. (2013), Babawale (2013), Atilola (2013), Effiong (2015) and Adegoke (2016) in Nigeria on other purposes of valuation.

The factors that were identified in literature but are not significant in this study are academic qualification, professional qualification, client influence and absence of professional sanctions for negligence and misconduct. Ayedun et al. (2012) earlier identified academic qualification of the valuer as one of the causes of variance in valuation. In the same manner, the study by Adegoke (2016) concluded that variance in valuation is traceable to valuer professional qualifications. The reason for disconfirming of these two sub-factors under the valuer characteristics could be due to the fact that the earlier studies that identified them did not directly focus on rating valuation.

Furthermore, client influence as a factor was identified as a potential cause of variance in mortgage valuation by Boyd and Irons (2002) in the popular Meyer Centre case and in some other non-statutory valuation studies such as Harvard (2001), and Bretten and Wyatt (2001) in the UK; also Ayedun et al. (2012), Akinjare et al. (2013), Effiong (2015), and Adegoke (2016) in Nigeria. However, this factor is not significant in this study. The reason for this divergent result might be that rating valuation involves some form of cross-checking during the display of the valuation list. The process in the display of the valuation list would have prevented client influence. It is therefore not a coincidence that previous studies that had either made comments of property assessment such as Oni and Ajayi (2011), Babawale and Nubi (2011), Atilola (2013) and Babawale (2013). The study by Munshifwa et al. (2016) was an empirical study on the factors causing variance in rateable values and did not mention or identify client influence as a significant factor. In addition, it could be because these studies covered both valuation inaccuracy and valuation variance.

Finally, the absence of professional sanctions was identified as one of the factors that causes variance in rating valuation in Tanzania as reported by Kelly and Musunu (2000). It is surprising that the absence of professional sanctions for negligence and misconduct has no significant influence on variance in rateable values in this study. Sanctions are a medium of cautioning erring members of the estate surveying and valuation profession on all their professional engagements. Even as it relates to valuation, in respect to the purpose of valuation, sanctions ought to be in place. Nevertheless, one may conclude that professional sanctions are not significant in this study because the motive behind objection and appeal is to have a fair rateable value. The contrary is obtainable in the non-statutory valuation, in particular mortgage valuation. In most non-statutory valuations, the intent of establishing variance is to claim damages and possibly instituting 
PLANNING MALAYSIA

Journal of the Malaysia Institute of Planners (2019)

negligence charges against the valuers as in the Meyer Centre case (Boyd \& Irons, 2002).

\section{CONCLUSION}

In conclusion, this study has provided information on the factors that could cause variance in property assessment. In order for valuation to be relevant in rating administration, the identified causes of variance in rateable values must be given the utmost attention it deserves in any rating valuation exercise. Hence, this would guarantee the future existence of the profession of estate surveying and valuation through greater client confidence and patronage.

\section{ACKNOWLEDGEMENT}

This research was funded by Research University Grant Scheme of Universiti Teknologi Malaysia Vot. 14H05.

\section{REFERENCES}

Achu, K. (2013). Client influence on property valuation: A literature review. International Journal of Real Estate Studies, 8(2), 24-47.

Adegoke, O. J. (2016). Effects of valuation variance and inaccuracy on Nigerian commercial property market: An empirical study. Journal of Property Investment \& Finance, 34(3), 276-292.

Akinjare, O. A., Iroham, C., \& Oloke, C. O. (2013). Valuation discrepancies in the value opinion of professional valuers' in Lagos, Nigeria. International Journal of Economy, Management and Social Sciences, 2(6), 272-276.

Al-Mustapha, A. A., \& Hamza, M. S. (2016). Determinants of informal sector tax evasion in Sokoto Metropolis. Igbinedion University Journal of Accounting, 2, 127-147.

Arowosegbe, A. A. \& Mohamed, S. F. (2015). A systematic change management capability maturity assessment framework for contracting organizations. American Scientific Research Journal for Engineering, Technology and Sciences, 13(1), 88-96.

Atilola, M. I. (2013, August). Reconciling the provisions of the Land Use Act and the Kwara State Land Charge Law. West Africa Built Environment Research (WABER). August 12-14, 2013, Accra, Ghana.

Atilola, M. I., Kamarudin, N., Achu, K., \& Ibisola, A. S. (2016). A review of valuation impact on property tax. Sains Humanika, 8(4-3), 17-23.

Ayedun, C. A., Oloyede, S. A., \& Durodola, O. D. (2012). Empirical study of the causes of valuation variance and inaccuracy in Nigeria. International Business Research, 5(3), 71-80.

Babawale, G. K. (2008). An evaluation of factors influencing inaccuracy in residential property valuation in Lagos Metropolis (Doctoral dissertation). Univeristy of Lagos, Nigeria.

Babawale, G. K. (2013). Designing appropriate valuation model for sustainable property tax systems in developing countries. International Journal of Law and Management, 55(3), 226-246. 
Moses Idowu Atilola, Azizah Ismail, Kamalahasan Achu, \& Ahmad Ariffian Bujang

An Evaluation of Factors Causing Variance in Property Assessment

Babawale, G. K., \& Nubi, T. (2011). Property tax reform: An evaluation of Lagos State Land Use Charge, 2001. International Journal of Law and Management, 53(2), $129-148$

Bello, K. B. (2014). Evasion and avoidance as forms of tax non-compliance: A critical review. Sains Humanika, 2(3), 39-42.

Bond, P. H., \& Brown, P. (2017). Rating valuation: Principles and practice (4 ${ }^{\text {th }}$ ed.). London: Routledge.

Boyd, T., \& Irons, J. (2002). Valuation variance and negligence: The importance of reasonable care. Pacific Rim Property Research Journal, 8(2), 107-126.

Bretten, J., \& Wyatt, P. (2001). Variance in commercial property valuations for lending purposes: An empirical study. Journal of Property Investment \& Finance, 19(3), 267-282.

Creswell, J. W. (2014). Research design qualitative, quantitative and mixed methods approaches ( $4^{\text {th }}$ ed.). California: Saga Publications.

Crosby, N. (2000). Valuation accuracy, variation and bias in the context of standards and expectations. Journal of Property Investment \& Finance, 18(2), 130-161.

Effiong, J. B. (2015). A comparative study of valuation variance and accuracy between Nigeria and the UK. International Letters of Social and Humanistic Sciences, 57, 94-105.

Estate Surveyors and Valuers Registration Board of Nigeria [ESVARBON] (2014) Register of registered estate surveyors and valuers entitled to practise estate surveying and valuation in the Federal Republic of Nigeria (2014 ed.).

Fatoki, J. O. (2014). An empirical study of tax evasion and tax avoidance: A critical issue in Nigeria's economic development. Journal of Economics and Sustainable Development, 5(18), 22-26.

Hager, D., \& Lord, D. (1985). The property market, property valuations and property performance measurement. London: Institute of Actuaries.

Hair, J. F., Black, W. C., Babin, B. J., Anderson, R. E., \& Tatham, R. L. (1998). Multivariate data analysis: A global perspective. New York: Pearson.

Harvard, T. (2001). Valuation reliability and valuer behaviour. Research Papers Funded by Royal Institution of Chartered Surveyors Foundation Research.

Ismail, A., Bujang, A. A., Jiram, W. R. A., Zarin, H. A., \& Jaafar, M. N. (2015). Factors affecting the housing financing of Bumiputera in Iskandar Malaysia. Journal of Economics, Business and Management, 3(11), 1031-1036.

Kayuza, H. M. (2014). The dilemma of implementing property taxation in Tanzania amidst unending search for yielding strategy, Lessons from Dar es Salaam LGAs. Journal of Land Administration in Eastern African, 2(1), 117-127.

Kelly, R. (2013). Making property tax work (International Center for Public Policy Working Paper 13-11). Georgia: Andrew Young School of Policy Studies, Georgia State University.

Kelly, R., \& Musunu, Z. (2000). Implementing property tax reform in Tanzania (Lincoln Institute of Land Policy Working Paper). Lincoln Institute Product.

Mohammad, N. E., Ali, H. M., \& Jasimin, T. H. (2018). Valuer's behavioural uncertainties in property valuation decision making. Planning Malaysia, 16(1), 239-250.

Munshifwa, E. K., Jain, N., Kaunda, B. S., Masiba, L., Lungu, J., Chunda-Mwango, N., ... \& Ngoma, W. (2016). Variances in rateable values in rating practice in 
PLANNING MALAYSIA

Journal of the Malaysia Institute of Planners (2019)

Zambia: The role of mental models in value assessment. Pacific Rim Property Research Journal, 22(2), 181-201.

Nasir, A. M. (2006). Valuation variance of commercial properties in Malaysia. Pacific Rim Property Research Journal, 12(3), 272-282.

NIESV Kwara State Branch (2015). List of Registered Estate Surveyor and Valuer in Kwara State, NIESV Kwara State Register.

Estate Surveyors and Valuers Registration Act, Cap E13 Law of the Federation 2007 (Nigeria).

Oni, A. O., \& Ajayi, C. A. (2011). Effects of property tax on sustainable housing delivery in Lagos State, Nigeria. Journal of Sustainable Development, 4(1), 173-192.

Ross, J. M. \& Duncan, D. (2012, November). Controversies in property assessment. 2012 Annual Conference of the National Tax Association. November 15-17, 2012, Providence, RI.

Salleh, R. (2009). Critical success factors of project management for Brunei construction projects: Improving project performance (Doctoral dissertation). Queensland University of Technology, Australia.

UN-HABITAT (2013). Property tax regimes in Europe, Nairobi: United Nations Human Settlements Programme

Received: $28^{\text {th }}$ October 2018. Accepted: $1^{\text {st }}$ March 2019 